\title{
The effect of batter refrigeration on the characteristics of high-fibre muffins with oil replaced by a protein-based fat substitute
}

\author{
Magdalena J C Bosman, Hester H Vorster, Carole Setser \& HS Steyn
}

\begin{abstract}
OPSOMMING
As deel van ' $n$ sistematiese proses in die ontwikkeling van 'n laevet- hoëvesel-muffin, word die invloed van olievervanging en verkoeling van die beslag op die kwaliteitseienskappe van die muffins gerapporteer. Bykomend tot die toenemende vraag na laevet-hoëveselprodukte in ' $n$ poging om vetinname en dus risiko vir chroniese siektes te verlaag, plaas die verbruiker al groter klem op die beskikbaarheid van varsgebakte produkte. Vinnige broodjies soos muffins, wat van voorafbereide, verkoelde beslag vars gebak word, kan help om in hierdie behoeftes te voorsien. Daar is egter min bekend oor die invloed van verkoeling van enige laevet- hoëveselbeslag op die kwaliteitseienskappe en mikrobiologiese tellings van die varsgebakte produk.
\end{abstract}

Die doel van hierdie studie was dus om die sintuiglike en fisiese eienskappe van hoëveselmuffins wat vars gebak is van beslag wat óf vars berei is óf vir 24 en 48 uur onderskeidelik verkoel is, te vergelyk. Die eienskappe van muffins waarin geen (kontrole), $80 \%$ of $100 \%$ van die olie met Simplesse $\AA$, 'n proteïengebaseerde vetvervanger vervang is, is ondersoek. Bykomend is mikrobiologiese toetse (aërobiese mesofiele bakterietellings, asook giste en skimmels) op die gebakte produk gedoen.

'n Onvolledige, gebalanseerde blokontwerp met twee faktore is gebruik, naamlik die vlak van olievervanging (geen, $80 \%$ en $100 \%$ ) en drie periodes van beslagverkoeling (geen, 24 en 48 uur). Die muffinbeslag is berei soos gerapporteer (Bosman et al, 1996). Beslag wat nie verkoel is nie (zero-verkoelingstyd) is direk na hidratering gebak. Die verkoelde beslag is by $0-4^{\circ} \mathrm{C}$ vir 24 en 48 uur gestoor en vir 60 min by kamertemperatuur gehou voordat dit gebak is. Sintuiglike evaluering en fisiese bepalings op die varsgebakte produk is gedoen met metodes soos reeds beskryf (Bosman et al, 1996; Bosman et al, 1998). Mikrobiologiese tellings is met die SABS metode 756 en ISO metode 7954 uitgevoer. Twee- en eenrigting variansie-analises met Tukey se meervoudige vergelykende toetse is gebruik om die statistiesbetekenisvolheid van die effek van olievervanging en verkoeling van die beslag op alle gemete veranderlikes te bepaal. Die verwantskap tussen sintuiglike en fisiese veranderlikes is met Pearson produk-moment korrelasies getoets en trosanalises (met Euclidiese afstande) is gebruik om ooreenkomste tussen die veranderlikes te meet.

Die resultate het getoon dat, alhoewel beide olievervanging en verkoeling van die beslag byna al die sintuiglike en fisiese eienskappe van muffins betekenis- vol beïnvloed het, die omvang van die verskille relatief klein was en dat al die muffins ten spyte van olievervanging of verkoeling van die beslag, hoë tellings vir al die veranderlikes verkry het. Geen verskille in die mikrobiologiese tellings is waargeneem nie. Die gemiddelde totale tellings van die mesofiele aërobe bakterieë $\left(5,0 \times 10^{2}-6,3 \times 10^{2}\right.$ $\mathrm{CFU} / \mathrm{g}$ ) was laer as die toelaatbare aanbevole kriteria. Geen giste of skimmels is in enige van die muffins waargeneem nie.

Die omvang van verskille as gevolg van olievervanging op die sintuiglike en fisiese eienskappe van voorkoms, tekstuur, smaak, volume en hoogte, voginhoud en die persentasie vogverlies tydens die bakproses, was oor die algemeen groter as die effek van verkoeling van die beslag vir 24 of 48 uur voor die bakproses op die meeste van hierdie veranderlikes. Wanneer die effek van beslagouderdom binne elke formule vergelyk word, het dit duidelik geblyk dat meer van die eienskappe van die kontrole muffins deur verkoelde opberging van die beslag beïnvloed is as van die eksperimentele muffins. Dit dui daarop dat Simplesse ${ }^{\circledR}$ waarskynlik die stabiliteit van die muffinbeslag verhoog het sodat dit minder as die kontrole muffins tydens verkoelingsperiodes van 24 en 48 uur voor die bakproses, verander het. Beide die kontrole en eksperimentele muffins wat van koelopgebergde beslag gebak is, was oor die algemeen effens donkerder, fermer, minder krummelrig en kleiner in volume en hoogte as dié van varsbereide beslag. Hierdie resultate, tesame met die lae bakterietellings, dui daarop dat waar nodig, die laevethoëveselmuffinbeslag met Simplesse $\AA$ vir periodes van 24 of 48 uur by $0-4{ }^{\circ} \mathrm{C}$ met veiligheid verkoel kan word voordat dit gebak word om steeds ' $n$ produk van hoë kwaliteit te lewer.

- Dr MJC Bosman and Prof HH Vorster

School of Physiology, Nutrition and Family Ecology

Potchefstroom University for Christian Higher Education

\section{- Prof C Setser}

Department of Foods and Nutrition

Kansas State University, Manhattan

\section{- Prof HS Steyn}

Statistical Consultant Services

Potchefstroom University for Christian Higher Education

\section{Acknowledgement}

The authors thank Mr. Stanley Cauvain for useful advice and guidance, Mrs. E Pienaar for technical assistance and the Potchefstroom University for Christian Higher Education for financial support. 


\section{INTRODUCTION}

The availability of low-fat products could contribute to lower fat intake of a population aiming to lower risk of chronic diseases of lifestyle. A low-fat, high-fibre muffin containing various levels of fat substitute was developed and evaluated by Bosman et al (1996) in our laboratory. The characteristics of these muffins (Bosman et al, 1996), dietitians' attitudes towards fat substitutes and acceptability of the low-fat high-fibre muffins (Bosman et al, 1997a), consumer acceptance (Bosman et al, 1997b) as well as the effects of oil replacement and storage of the baked muffins on quality characteristics (Bosman et al, 1998) were systematically examined. In this contribution we report on the effect of batter refrigeration on the quality characteristics of muffins with different percentages of oil replacement.

In addition to the growing demand for low-fat, highfibre products (Faridi, 1995; Newman et al, 1998), consumers are attaching even greater importance to freshness. In fact, Food Technology's "Top Ten Trends to Watch and Work On" cites freshness as the second most important food industry trend (Sloan, 1994). According to the Health Focus Survey of US consumers, fresh tops the list of the most desirable label claim (57\%) with fat free a distant second (Faridi, 1995). There is no literature on South African consumer preferences available, but there is no reason to assume that opinions of affluent consumers will differ. In response to the consumer's quest for fresh food, scientists and food service operations are searching for innovative ways to offer nutritious, fresh products in a cost and time effective way (Gibson, 1995). Freshly baked products such as bread and muffins have special appeal for consumers in search of acceptable nutritively dense foods. Consumer needs for foods that are convenient, high-quality and healthy can be partially served by refrigerated batters for quick breads such as muffins (Dorko \& Penfield, 1993a). However, published research on refrigerated batters and the effect of high-fibre content, oil replacement and batter refrigeration on freshly baked product quality is limited. Moreover, little is known about the microbiological safety of these products. The chief microbiological concern associated with extended shelf life served by refrigerated batters, centres on mesophilic and psychrotrophic micro-organisms such as yeasts and moulds that could grow during extended refrigerated storage or temperature abuse (Marth, 1998).

According to Dorko and Penfield (1993a) the moisture content and shape of bran muffins baked from refrigerated batters were not affected by batter storage while the muffin crumb became darker, less crumbly, although easier to chew as batter storage time increased. Quinn (1995) reported on declining height and tunnelling of baked muffins after batter refrigeration in previous studies done at a hospital changing from a conventional foodservice system to a cook-chill system. Presoaking the cereal bran and adding the flour during the last step of mixing appeared to im- prove the texture of these muffins. Baking muffins at higher temperatures contributed to higher baked heights although the heights of muffins baked from refrigerated batters decreased as storage time increased.

Information on the effect of refrigeration on the quality of high-fibre muffins in which the oil was replaced, could thus be important in food services. If the batter could be prepared during a slack period one or two days ahead and freshly baked when needed, without adverse effects on quality, this could contribute to more efficient use of employee time and equipment in producing a fresh baked product.

\section{OBJECTIVE}

The objective of this study was to evaluate and to compare the effect of different percentages of oil replacement with Simplesse ${ }^{\circledR}$ on the sensory and physical characteristics and microbiological quality of high-fibre muffins. Muffins freshly baked from either freshly prepared batter or batter refrigerated for $24 \mathrm{~h}$ or $48 \mathrm{~h}$ respectively were also compared within each period of batter refrigeration and within each formula .

\section{MATERIALS AND METHODS}

\section{Experimental design}

High-fibre muffins with zero $\%, 80 \%$ and $100 \%$ oil replacement with Simplesse ${ }^{\circledR}$ Dry 100 baked from freshly prepared and refrigerated batters were studied. The experiment was an incomplete balancedblock design with two factors: three levels of oil replacement (zero \%, $80 \%$ and $100 \%$ ) and three periods of batter refrigeration (freshly prepared (zero), 24 $\mathrm{h}$ and $48 \mathrm{~h}$ refrigerated, respectively) with four replications as shown in Figure 1.

\section{Muffin formulations and preparation}

Batters of high-fibre muffins with zero $\%, 80 \%$ and $100 \%$ oil replacement with Simplesse ${ }^{\circledR}$ (full-fat control Formula 1, Formula 2 and Formula 3 respectively) were freshly prepared as described by Bosman et al (1996). The batters were mixed only until well moistened but still lumpy (20 strokes) and were immediately poured into one-litre plastic buckets with tight sealing lids and left at room temperature to hydrate for $1 \mathrm{~h}$. The buckets were coded according to the formulas and the three periods of batter refrigeration. Batter samples to be baked freshly prepared (zero-time refrigeration) were scooped and weighed (70 g) into each cup of a standard 12 count aluminium muffin pan (sprayed with non-stick spray) immediately after hydration. Those to be baked from refrigerated batters were stored in a refrigerator at $0-4^{\circ}$ $\mathrm{C}$ for $24 \mathrm{~h}$ and $48 \mathrm{~h}$ respectively. The refrigerated batter was held at room temperature for $1 \mathrm{~h}$ before samples were scooped into the pans for baking. Muffins were baked, cooled and packaged at the end of 


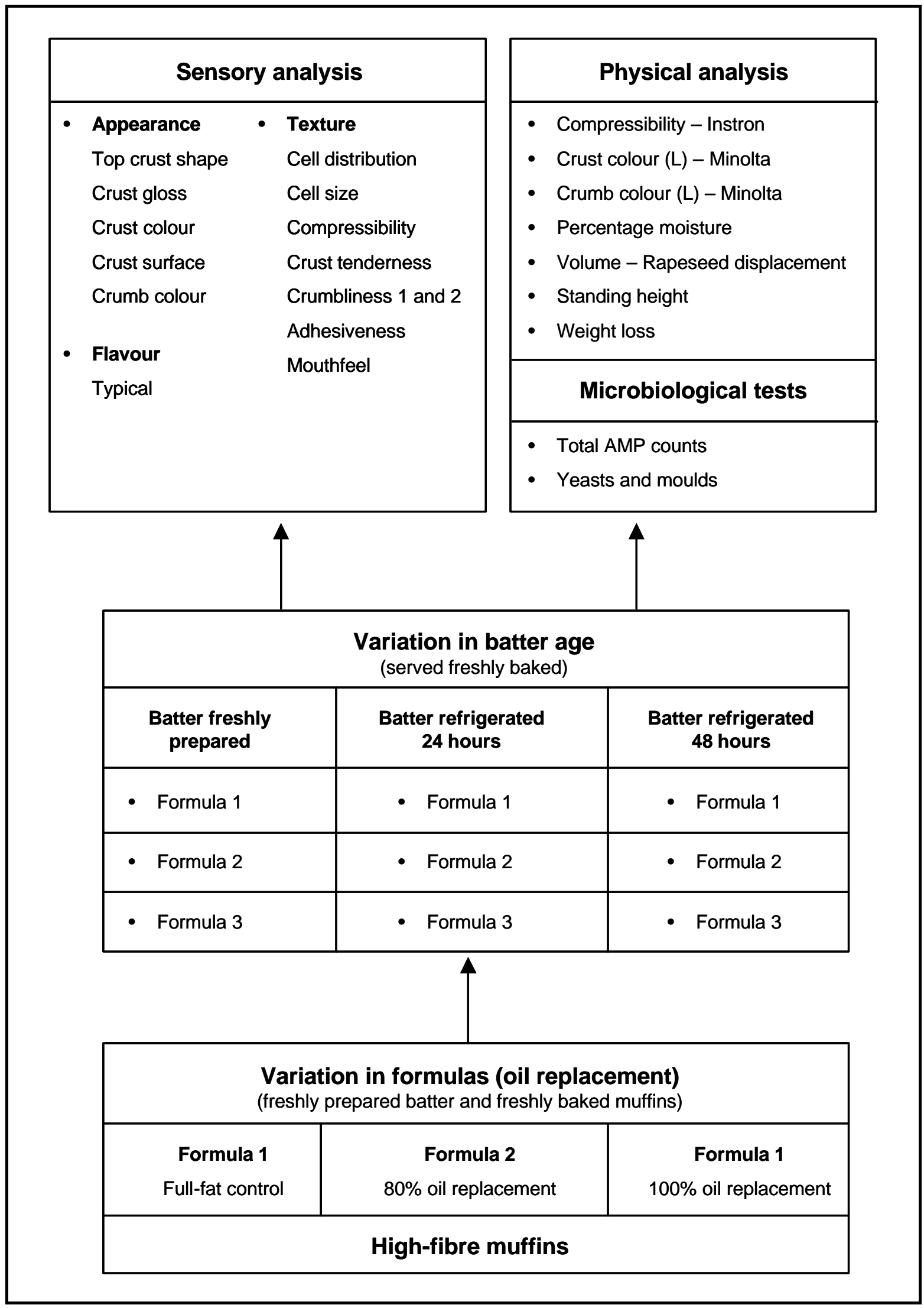

FIGURE 1: $\quad$ EXPERIMENTAL DESIGN - THE EFFECT OF OIL REPLACEMENT AND BATTER REFRIGERATION ON THE CHARACTERISTICS OF HIGH-FIBRE MUFFINS 
each batter refrigeration period as described previously (Bosman et al, 1996). All baked samples were stored in plastic bags at room temperature for only $1 \mathrm{~h}$ until the sensory and physical measurements could be conducted.

\section{Sensory evaluation}

Sensory analyses were conducted by an analytical descriptive panel (8 panellists) selected and trained as described by Bosman et al $(1996 ; 1998)$. The sensory evaluation of the muffins was performed according to the sensory attributes defined and scale anchors set by the panel as summarised in Table 1 (Bosman et al, 1998). A six-point Likert-type rating scale, where 1 represents the minimum and 6 the maximum intensity of each attribute, was used. The attributes evaluated were: Appearance (top crust shape, crust gloss, crust colour lightness, crust surface roughness, crumb colour lightness); Texture (cell distributions, cell size, compressibility, crust tenderness, crumbliness at initial bite, crumbliness after chewing, crumb tenderness, mouthfeel moistness, adhesiveness); Flavour (typical, sweet). Evaluations were conducted in partitioned booths in ten sessions over a five-week period under controlled conditions. Two series of three samples each (one sample per formula) were presented individually on small white coded plates on a white tray. Water at room temperature was provided for mouth rinsing before and between each of the three samples in a series. Apple slices were served in the 10-minute break between the two series of each session.

\section{Physical determinations}

Compressibility was determined by using an Instron Universal Testing Machine (Model MNN 44) equipped with a flat plunger (21 $\mathrm{mm}$ diameter) to compress a sample of $25 \mathrm{~mm}$ thickness at $40 \%$ of the original height at a cross-head speed of $100 \mathrm{~mm} / \mathrm{min}$. The reading was taken of the force (Newton) necessary to compress the sample $25 \%(6,25 \mathrm{~mm})$. One reading was taken per sample for four samples per formula per batter age. The exact sample was obtained by cutting a slice of $25 \mathrm{~mm}$ vertically from the centre of each muffin.

Colour was measured by obtaining lightness $(\mathrm{L})$ values for the external top surface (crust colour) and internal cut surface (crumb colour) of four muffins per formula per batter age using a Minolta colorimeter (Model CR200) which was set against a white reference tile $(L=97,79, a=-5,55$ and $b=+7,35)$.

The moisture content of the muffins was determined in duplicate per batch $(2 \times 4)$, using AOAC method 22-8 (AOAC, 1984)

Additional physical determinations, namely standard height, volume and percentage moisture loss during baking were also done. The standard height of eight muffins from each batch was measured at the centre of each muffin, while the volume of each group of eight muffins was determined by rapeseed displacement. Percentage moisture loss during baking was calculated from the mass before and after the baking of eight muffins from each batch.

\section{Microbiological counts}

The total aerobic mesophilic plate count (AMP) of viable bacteria was determined and the yeasts and moulds were counted in duplicate on each sample of baked muffins per session. The tests were carried out in accordance with the standard methods of the SA Bureau of Standards (SABS), namely SABS Method 756 and ISO Method 7954 respectively. The microbial counts were reported as colony-forming units per gram (CFU/g).

\section{Statistical analyses}

Two-way and one-way analyses of variance (ANOVA) and Tukey's multiple comparison tests $(p<0,05)$ were applied to the sensory, physical and microbiological data to determine whether the muffins from the different formulas differed significantly within the batter refrigeration periods or within formulas at different batter refrigeration periods. The relationship among the sensory and physical variables was analysed by means of Pearson's product-moment correlations. Cluster analyses were performed separately on the sensory and physical data by linking the types by the average linkage method using the Euclidian distances between the types. The SAS Institute, Inc. (1988) programme was used for data analyses.

\section{RESULTS AND DISCUSSION}

The analyses of variance of the sensory and physical results are summarised in Tables 2 to 5 . Tables 2 and 3 demonstrate how the sensory and physical characteristics of the high-fibre muffins with different levels of oil replacement varied when baked from freshly prepared batter or baked from batter that was refrigerated for 24 or 48 hours, respectively. Tables 4 and 5 compare the effects of different batter ages on the characteristics of the muffins per formula. The results revealed that both independent variables, namely oil replacement and batter refrigeration had significant effects on almost all the characteristics measured in this study.

No differences in microbiological counts were observed. The mean total counts of the aerobic mesophilic bacteria (AMP) varied between 5,0 X $10^{2}$ and $6,3 \times 10^{2} \mathrm{CFU} / \mathrm{g}$, which are substantially lower than the advisory criteria and fall within the microbiological profile of baked products that are in the range of 10$10^{3} \mathrm{CFU} / \mathrm{g}$ (Elliot, 1980:696), indicating high bacterial quality for all the muffin variations. No counts of yeast and moulds were detected in any of the samples that were analysed, even after refrigerated storage $\left(0-4^{\circ}\right.$ C) of the baked muffins for seven days irrespective of oil replacement or batter age. These results were due to safety precautions taken such as sanitary handling 


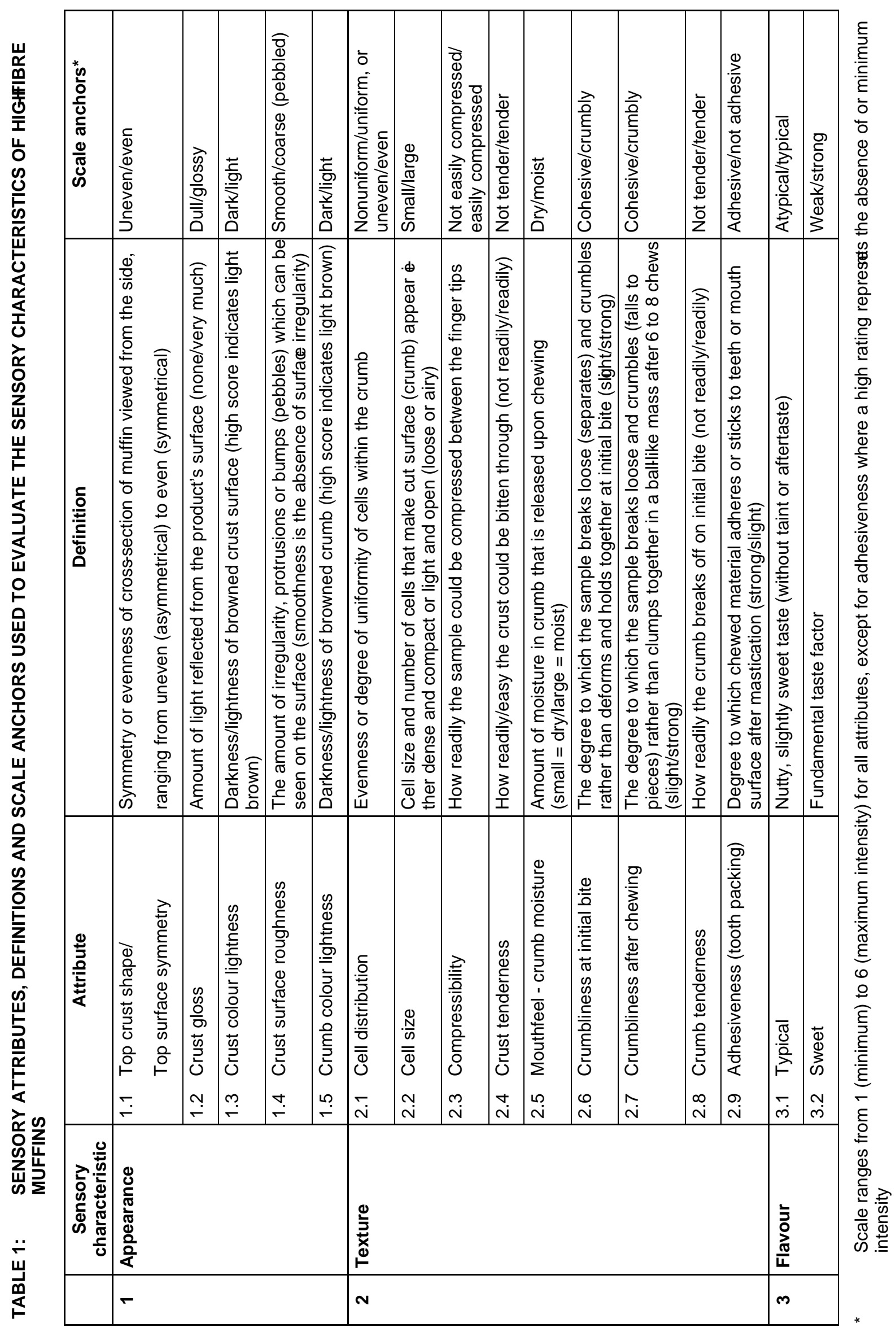



AND SERVED FRESHLY BAKED

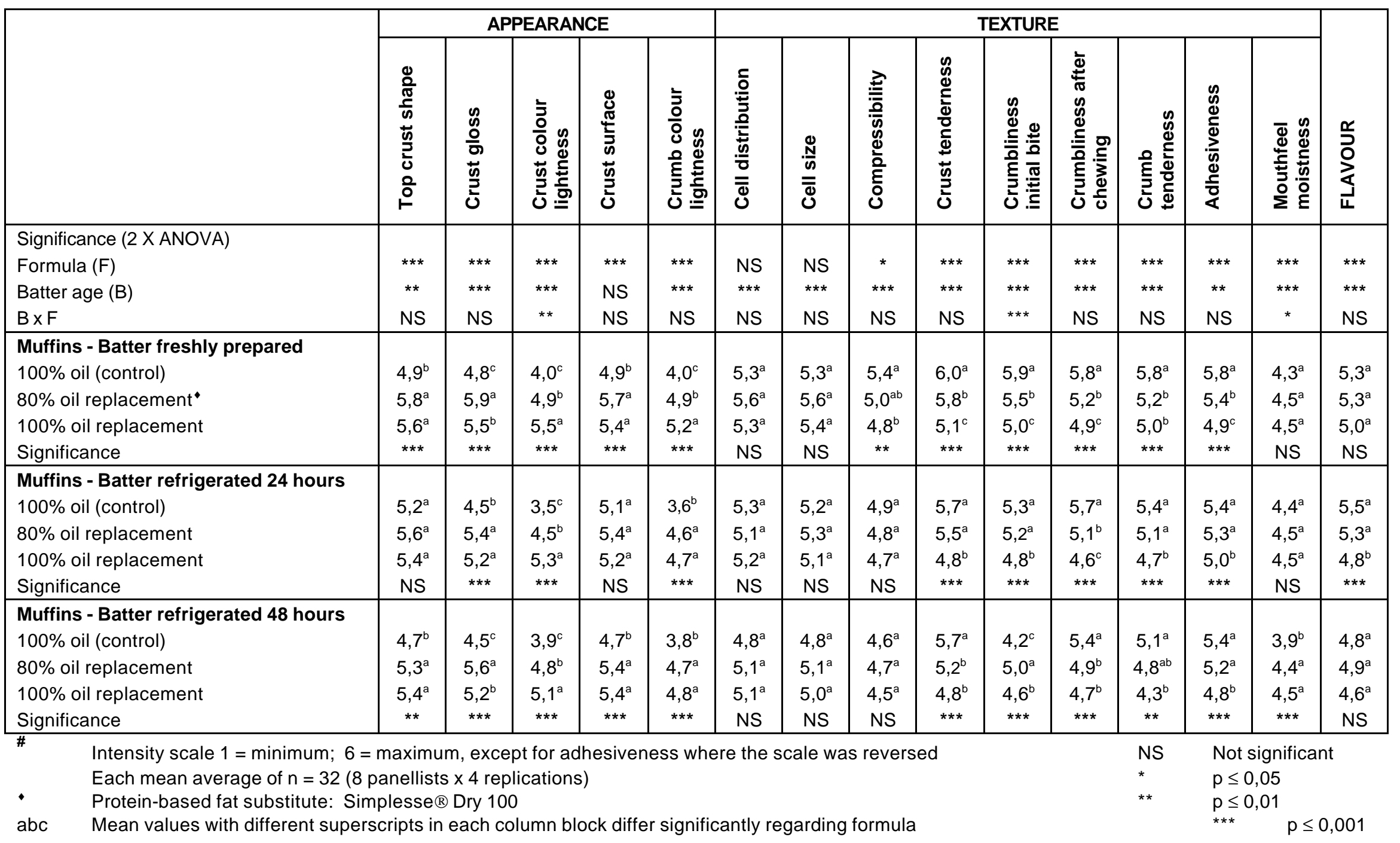


and environment, safe temperature $\left(0-4^{\circ} \mathrm{C}\right)$ and short time of batter refrigeration, high baking temperature $\left(180^{\circ} \mathrm{C}\right)$ as well as the water-binding capacity of Simplesse $\AA$ due to its high protein and lactose content (McWilliams, 1997:351; Marth, 1998; Corliss, 1992). Since the bacterial counts were not affected by either oil replacement or batter refrigeration, these were not included in Tables 3 and 5.

Effect of oil replacement on sensory and physical characteristics of high-fibre muffins within each period of batter refrigeration (batter age)

According to the results analysed by two-way ANOVA presented in Tables 2 and 3 , oil replacement (Formula) had a statistically significant effect $(p<0,05)$ on all the sensory and physical characteristics of the muffins except cell distribution and cell size as determined within each different period of batter refrigeration, namely freshly prepared (zero), refrigerated for $24 \mathrm{~h}$ or $48 \mathrm{~h}$, respectively.

Sensory analysis When the appearance of the muffins of the different formulas was compared within each batter age, a general trend was observed. The experimental muffins with Simplesse ${ }^{\circledR}$ were rated significantly differently for exhibiting a glossier, lighter brown crust and crumb colour than the full-fat control muffins baked from either freshly prepared or refrigerated batters. The glossier and lighter brown crust colour with increased fat replacement could be linked to the effect of the high lactose content of Simplesse $\AA( \pm 36 \%)$ producing a glossier crust and the fact that a glossier surface would reflect more light resulting in a lighter crust colour. The lighter crust and crumb colour of the experimental muffins could also, in spite of the higher lactose levels, be due to the inhibition of the Maillard reaction (carbonyl-amine) accomplished by the acidic $\mathrm{pH}$ due to the plain yoghurt containing lactic acid $(\mathrm{pH} 4,3)$ used as liquid and the effect of the higher moisture content of these formulas acting as a dilute in the batters containing Simplesse $\AA^{\circledR}$ (Bean \& Setser, 1992:168,175). According to Alais and Linden (1991:88) excess water always retards the development of the Maillard reaction, first by dilution of the medium and then by the inhibiting role it plays as it is one of the products formed by the reaction. These significant differences in crust and crumb colour lightness between the experimental and full-fat muffins were partly confirmed by the instrumental results (Table 3 ). Contrary to these results no general trend occurred regarding the top crust shape and crust surface of the muffins within the different batter ages.

Comparing the texture of the muffins of the different formulas within each batter age also revealed some general trends. The full-fat control muffins were rated significantly higher having a more tender crust and a more crumbly, more tender and less adhesive crumb than the muffins with Simplesse $\AA^{\circledR}$. Fulton and Hogbin (1993) also reported on decreased muffin tenderness as fat levels decreased. Crust tenderness decreased with increased fat replacement irrespective of the bat- ter age. This could be due to the fact that fat is a very powerful inhibitor of starch retrogradation which could occur even during cooling in the fat-substituted muffins causing firming of the crust (Bean \& Setser, 1992:94). Crumb tenderness also tends to decrease with increased fat replacement at all three batter ages. According to McWilliams $(1997: 465,471)$ fat tenderises baked products by adsorption of the surface of gluten proteins, limiting the ease of hydration and inhibiting the development of a firm cohesive gluten structure, thus promoting tenderness in the full-fat control muffins. The muffins also tend to become less crumbly and more adhesive with increased fat replacement at all three batter ages. Simplesse ${ }^{\circledR}$ contributed to improved moisture holding, due to the high protein and lactose content, which increase cohesiveness and adhesiveness and decrease crumbliness (Corliss, 1992). The present results correspond with some of Armbrister and Setser's findings (1994), indicating that chocolate chip cookies made with Simplesse ${ }^{\circledR}$ Dry 100 were also less crumbly and slightly more cohesive. The results of this study differed, however, from their findings which indicated increased cell size and crumb tenderness with increased oil replacement.

The flavour of the full-fat control muffins did not differ significantly from that of the experimental muffins when baked from either freshly prepared or $48 \mathrm{~h}$ refrigerated batters and was described as typical, with a nutty and slightly sweet taste. It confirms the statement by Schirle-Keller et al (1994) that foods with protein-based fat substitutes should have a flavour profile that is similar to the profile of fat-containing products. The muffins with total oil replacement baked from 24hrefrigerated batter, were, however, perceived as significantly less typical in flavour than the full-fat control muffins and those with $80 \%$ oil replacement.

Physical determinations Compressibility was measured instrumentally as the force required to attain a specified compression (25\%) of a sample of specific thickness $(25 \mathrm{~mm})$. Thus the firmer the sample, the greater the force required and vice versa. According to Table 3 , the compression of experimental muffins required significantly more force as these muffins were significantly firmer or less compressible than the full-fat control muffins of all three batter ages. Thus, formula affected compressibility irrespective whether the batter was freshly prepared or refrigerated. Compressibility decreased with increased fat replacement. This finding agrees with the results of Cauvain (1991) who also indicated increased firmness of cakes with additional protein and reduced fat levels. These results also correspond with the findings of Conforti and Smith (1998) who showed that the crumb tenderness of muffins decreased when oil was replaced with a fat substitute. According to the Instron results, the muffins with partial oil replacement were significantly more compressible than those with total oil replacement when baked from freshly prepared batter but not when baked from $24 \mathrm{~h}$ or $48 \mathrm{~h}$ refrigerated batter. These differences were not confirmed by the sensory panel. Contrary to the sensory 


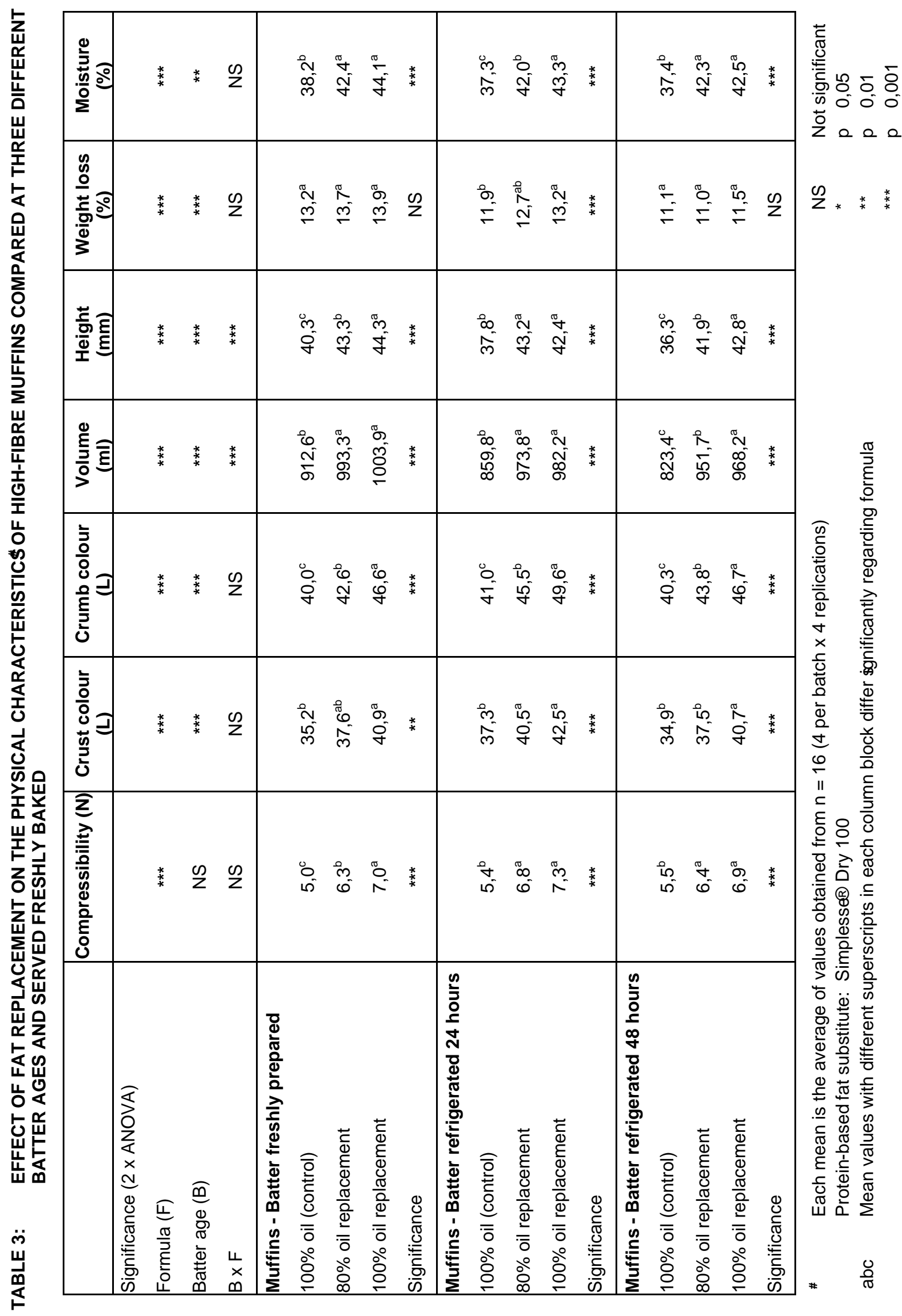



AND OIL REPLACED, SERVED FRESHLY BAKED

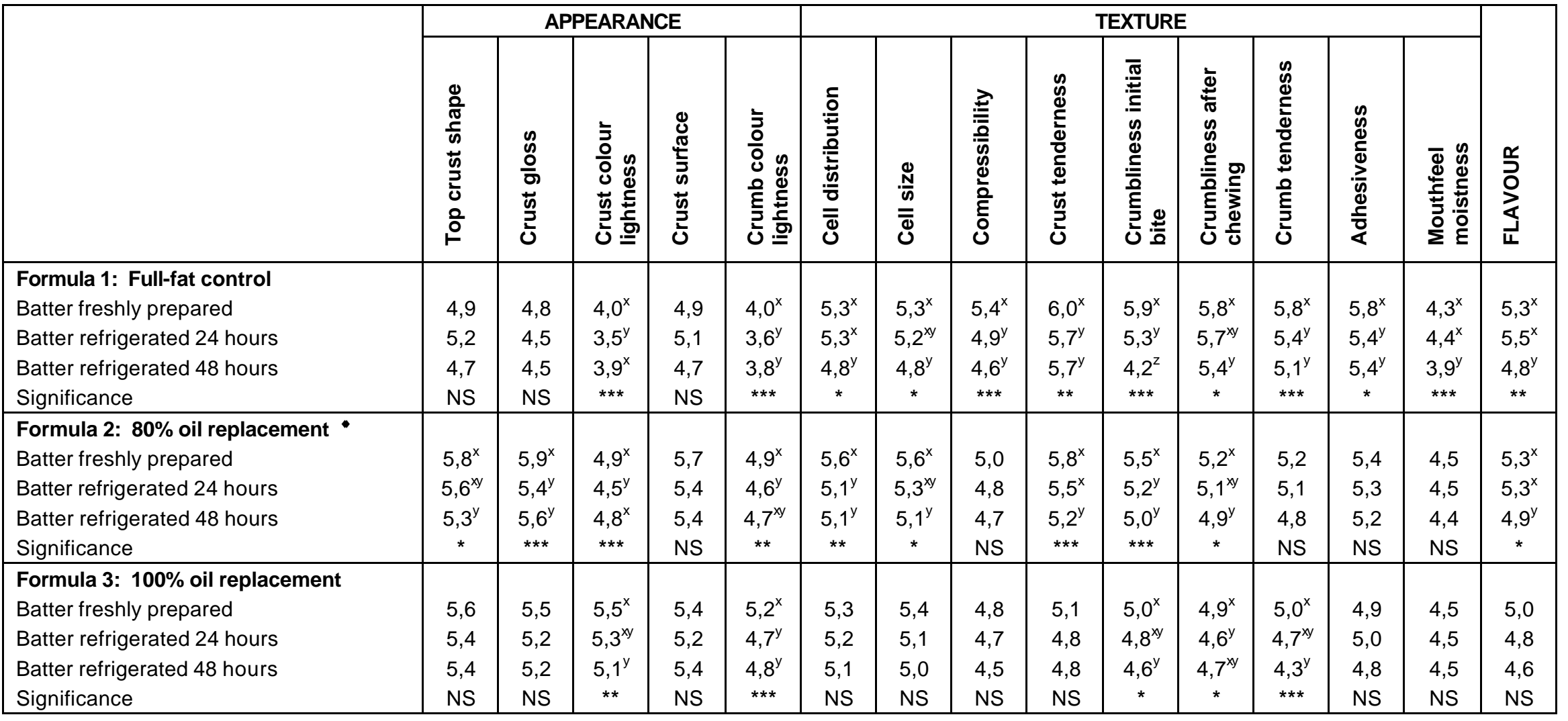

\# Intensity scale 1 = minimum; 6 = maximum, except for adhesiveness where the scale was reversed Each mean average of $n=32$ ( 8 panellists $\times 4$ replications)

- $\quad$ Protein-based fat substitute: Simplesse ${ }^{\circledR}$ Dry 100

xyz $\quad$ Mean values with different superscripts in each column block differ significantly regarding batter age

NS Not significant

* $\quad p \leq 0,05$

** $\quad p \leq 0,01$

$\star * * \quad p \leq 0,001$ 
results that showed no significant differences among the muffins of the different formulas, baked from either $24 \mathrm{~h}$ or $48 \mathrm{~h}$-refrigerated batters, the Instron results indicated that the full-fat control muffins were significantly more compressible than both experimental muffins baked from $24 \mathrm{~h}$ and $48 \mathrm{~h}$-refrigerated batters respectively.

Table 3 also presents the results of the instrumental analysis of colour lightness of the external (crust) and internal (crumb) surfaces. No significant differences were found between the crust colour of the fullfat control muffins and that of the muffins with $80 \%$ oil replacement on lightness (L-values) which were instrumentally obtained from muffins baked from freshly prepared and $48 \mathrm{~h}$-refrigerated batter. When baked from 24 h-refrigerated batter both experimental muffins exhibited significantly lighter crust colours than the full-fat control muffins.

The crust colour of the muffins with $100 \%$ oil replacement baked from freshly prepared and refrigerated batter was significantly lighter than the crust colour of the full-fat control muffins. The crumb colour of both formulas with protein-based fat substitute was significantly lighter than the crumb colour of the full-fat control muffins of all three batter ages, confirming the sensory results as discussed earlier. These results correspond with the findings of Conforti and Smith (1998) who reported a significantly lighter crumb colour in muffins as the percentage of fat substitute increased and with the finding of Matthews et al (1965) indicating a less brown crust colour in muffins with decreased levels of fat.

The experimental muffins with additional protein (Simplesse ${ }^{\circledR}$ ) and oil replacement exhibited increased volume and height compared to the full-fat control muffins baked from either freshly prepared or refrigerated batters. Results obtained by Cauvain (1991) also indicated increased cake volume with decreased fat levels and increased protein levels when skimmed milk powder was used. The increased volume and height with increased levels of fat substitution, irrespective of batter age, could be due to the additional sugar (lactose) and proteins contributed by Simplesse $\AA$. According to McWilliams (1997:465,472) sugar contributes sweetness and serves as a tenderising agent by retarding gluten development during mixing and by elevating the coagulation temperature of the structural proteins so that there is more time for cell walls to stretch and volume to increase before coagulation occurs to define the final volume and height of the baked product. The higher protein and moisture levels of the experimental muffins compared to the full-fat control muffins also contribute some leavening action due to the ability of protein to trap steam in the batter to increase volume and height of baked products (Charley, 1986:167,178). The finding of the present study, namely that the height of the muffins increased with decreased levels of oil, was contrary to the results of Fulton and Hogbin (1993) who found that the height of cakes was not affected by reduced fat levels.
Although no significant differences in percentage weight loss during baking occurred between the full-fat control and the muffins with oil replacement baked from either freshly prepared or $48 \mathrm{~h}$ refrigerated batters, the full-fat control muffins baked from 24 h-refrigerated batter showed significantly lower weight losses than the muffins with $100 \%$ oil replacement. This confirms the findings of Hogbin and Fulton (1992) and Conforti et al (1996), viz. that moisture loss in baked products tended to increase as the level of fat decreased.

In correspondence with the findings of Conforti and Smith (1998) the moisture content of the experimental muffins with Simplesse ${ }^{\circledR}$ was significantly higher than that of the full-fat control muffins irrespective of whether they were baked from freshly prepared or refrigerated batters. This could be due to the additional water in the experimental formulations for the hydration of Simplesse $\AA$ Dry 100 and its waterretention ability as it binds the water molecules through hydrogen bonds (Corliss, 1992). Although not significantly different from each other, when baked from freshly prepared or 48 h-refrigerated batter, the experimental muffins differed significantly from each other when baked from 24 h-refrigerated batter. These significant differences in the physical determination of moisture content were, however, not confirmed by the panellists' perception of sensory moistness. Although the fat-reduced muffins of all three batter ages were higher in moisture content, the panellists did not perceive those baked from freshly prepared batter and 24 h-refrigerated batter to be moister. Oil contributes to lubricity during mastication and creates an easier and smoother breakdown of the baked product, reducing the amount of saliva required for mastication and swallowing of the food item. The full-fat product could thus be perceived to be as moist, although lower in moisture content, than the fat-reduced product (Conforti \& Smith, 1998). In the case of the muffins baked from 48 h-refrigerated batter the significantly higher moisture content of the experimental muffins was, however, confirmed by the panellists' perception of higher sensory moistness. In contrast to the findings of Cauvain (1991) which showed decreased volume as moisture content increased, the muffins with Simplesse ${ }^{\circledR}$ in this study showed increased volume with increased moisture contents.

\section{Effect of batter refrigeration on the sensory and physical characteristics of the muffins per for- mula}

According to the results analysed by two-way ANOVA provided in Tables 2 and 3, batter refrigeration (batter age) had a statistically significant effect $(p<0,01)$ on all the sensory and physical characteristics of the muffins, except for crust surface, and compressibility (Instron Universal Testing Machine) within all the formulas compared to the muffins baked from freshly prepared batter. The results regarding the effect of batter refrigeration on the sensory and physical characteristics of the muffins per formula are summarised 
in Tables 4 and 5 respectively.

Sensory analysis When the appearance of the muffins baked from freshly prepared batter was compared with that of muffins baked from refrigerated batter per formula, only a few inconsistent significant differences were shown (Table 4).

Contrary to the appearance results, batter refrigeration had a statistically significant effect on all the sensory attributes pertaining to texture of the full-fat control muffins while only a few attributes of the muffins with partial oil replacement and even fewer of the muffins with total oil replacement were significantly affected. With the full-fat control muffins, the sensory score for crumbliness at initial bite was decreased as batter storage time increased. These results correspond with the findings published by Dorko and Penfield (1993b) which also showed that the crumbliness of full-fat muffins decreased with batter storage possibly because of increased hydration of the batter during storage although the moisture content of the baked muffins was not affected by batter refrigeration. The full-fat control muffins baked from $24 \mathrm{~h}$ refrigerated batter retained their texture attributes as did those baked from freshly prepared batter regarding cell size, cell distribution and mouthfeel moistness, but showed a significant decrease in compressibility, crust tenderness, crumb tenderness and an increase in adhesiveness. The control muffins baked from 48 h-refrigerated batter were rated as being significantly different from those baked from freshly prepared batter for all the textural attributes.

With the muffins with $80 \%$ oil replacement cell distribution, cell size, crust tenderness and crumbliness after chewing were significantly affected by $48 \mathrm{~h}$ batter refrigeration. Contrary to the findings of Dorko and Penfield (1993b) compressibility, crumb tenderness, adhesiveness and mouthfeel moistness were not significantly affected by batter refrigeration, possibly due to a stabilising effect of Simplesse® because of its water binding and emulsifying properties (Corliss, 1992).

In the case of the muffins with $100 \%$ oil replacement the effect of batter refrigeration was limited and decreased only the sensory ratings for crumbliness and crumb tenderness when baked from 48 h-refrigerated batter. With both experimental muffins compressibility was not affected by batter refrigeration. These sensory results were confirmed by the Instron results.

When the flavour of the muffins per formula was compared, the full-fat control muffins and the muffins with partial oil replacement were rated significantly less typical when baked from $48 \mathrm{~h}$-refrigerated batter than baked from freshly prepared or 24 h-refrigerated batters respectively. The flavour of the muffins with total oil replacement was not significantly affected by batter refrigeration.

Physical determinations When the Instron results on compressibility of the muffins were compared per formula, the muffins baked from freshly prepared and refrigerated batters did not differ significantly from each other, irrespective of the formula. This corresponded with the sensory results of the muffins with Simplesse $\AA$ but the sensory results of the full-fat control muffins baked from freshly prepared batter indicated that the muffins were significantly more compressible than those baked from $48 \mathrm{~h}$-refrigerated batter. This could be due to the effect of decreased crumbliness and increased adhesiveness on the sensory perception of compressibility.

Different periods of batter refrigeration per formula showed no significant differences in crust or crumb colour in terms of lightness (L) values for the full-fat control muffins while the effect on the experimental muffins was inconsistent.

Irrespective of formula, a very strong trend of reduced volume and height occurred with refrigeration of the batter. These results correspond with Quinn's findings (1995), who also reported on declining height of baked muffins as batter storage time increased. This could be due to the fact that sodium bicarbonate and yoghurt react quickly to produce carbon dioxide which could partly be lost during batter refrigeration (McWilliams, 1997:478). This problem could be reduced by using double-acting or slow-acting baking powders which are frequently used in refrigerated batter because it produces only a slight amount of carbon dioxide at room temperature and the remainder during baking (Campbell, 1992:324). The actual decrease in volume and height of the full-fat control muffins due to refrigeration was, however much more than that of the experimental muffins. It seems that the water binding and emulsification capacity of Simplesse $\AA$ stabilised and improved the expansion of the batter.

Irrespective of formula, a clear trend was observed regarding percentage weight loss during baking namely that the muffins baked from freshly prepared batter lost more water than those baked from $48 \mathrm{~h}$ refrigerated batter which could be due to prolonged water absorption and binding by the wheat bran during refrigeration. Although the full-fat control muffins baked from $24 \mathrm{~h}$ and $48 \mathrm{~h}$-refrigerated batters did not differ from each other regarding the percentage weight loss of the muffins, it was significantly less compared to that of the muffins baked from freshly prepared batter. With the muffins with partial oil replacement, the percentage weight loss was significantly decreased as batter storage increased whereas in the case of the muffins with total oil replacement only those baked from 48 h-refrigerated batter showed a significant decrease in weight loss.

A comparison of the moisture content of the muffins baked from freshly prepared or refrigerated batter per formula showed that the moisture content was not affected by batter refrigeration in the full-fat control muffins and in those with partial oil replacement. In the case of the latter the sensory ratings reflected the analysed moisture content. These results correspond with those of Dorko and Penfield (1993a) which also 


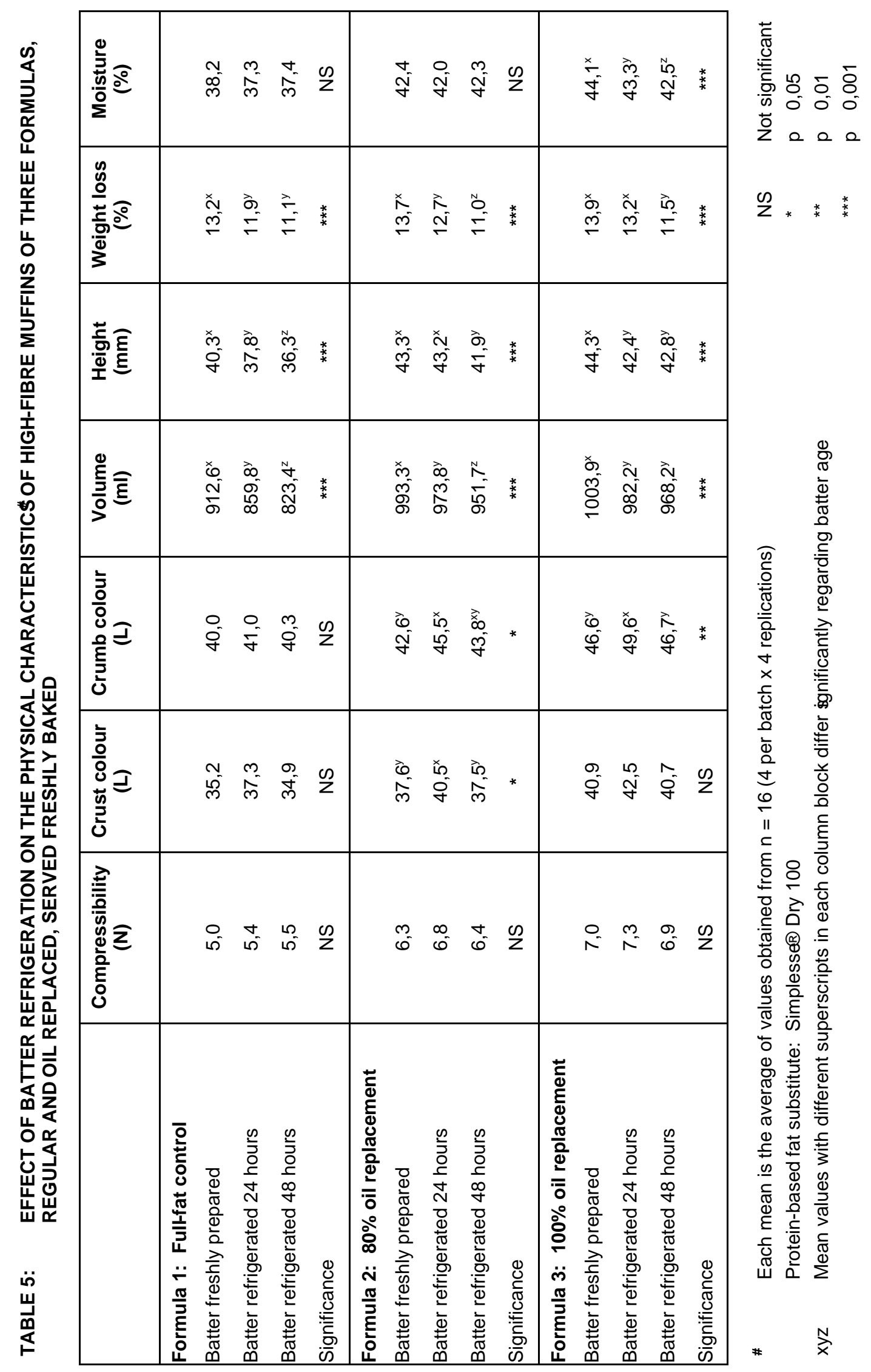


TABLE 6: SIGNIFICANT" CORRELATIONS IN SENSORY ATTRIBUTES AND BETWEEN SENSORY ATTRIBUTES AND PHYSICAL MEASURE-MENTS OF HIGH-FIBRE MUFFINS CONTAINING DIFFERENT PERCENTAGES OF SIMPLESSE $®$ AT THREE DIFFERENT BATTER AGES

\begin{tabular}{|c|c|c|c|c|c|c|c|c|c|c|c|c|c|c|c|c|c|c|c|c|c|}
\hline \multirow[b]{2}{*}{ ATTRIBUTES } & \multicolumn{5}{|c|}{ APPEARANCE } & \multicolumn{9}{|c|}{ TEXTURE } & \multirow[b]{2}{*}{ 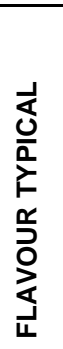 } & \multicolumn{6}{|c|}{ PHYSICAL } \\
\hline & 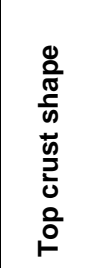 & 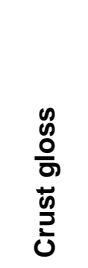 & 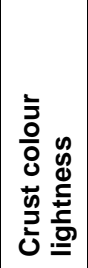 & 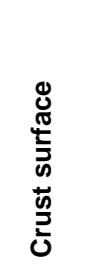 & 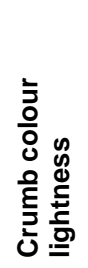 & 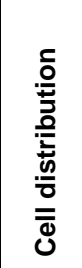 & $\begin{array}{l}\frac{N}{\omega} \\
\overline{\bar{D}}\end{array}$ & 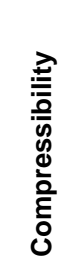 & 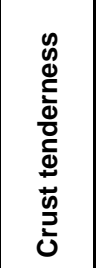 & 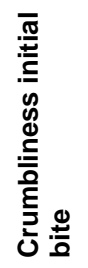 & 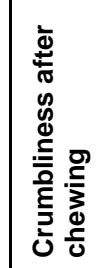 & 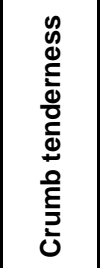 & 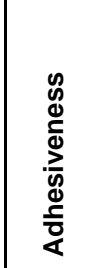 & 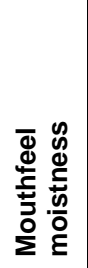 & & 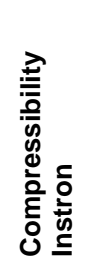 & $\begin{array}{l}\beth \\
\vdots \\
0 \\
0 \\
0 \\
\frac{1}{9} \\
0\end{array}$ & 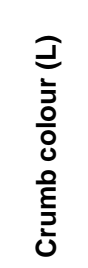 & $\frac{\stackrel{0}{\xi}}{\frac{3}{0}}$ & $\begin{array}{l}\frac{\overrightarrow{5}}{5} \\
\frac{0}{0} \\
\frac{1}{1}\end{array}$ & $\begin{array}{l}0 \\
\frac{0}{5} \\
\frac{0}{0} \\
\stackrel{0}{\Sigma}\end{array}$ \\
\hline $\begin{array}{l}\text { Appearance } \\
\text { Top crust shape } \\
\text { Crust gloss } \\
\text { Crust colour lightness } \\
\text { Crust surface } \\
\text { Crumb colour } \\
\quad \text { lightness } \\
\text { Texture } \\
\text { Cell distribution } \\
\text { Cell size } \\
\text { Compressibility } \\
\text { Crust tenderness } \\
\text { Crumbliness initial bite } \\
\text { Crumbliness after } \\
\quad \text { chewing } \\
\text { Crumb tenderness } \\
\text { Adhesiveness } \\
\text { Mouthfeel } \\
\text { Flavour } \\
\text { Typical } \\
\text { Sweet } \\
\text { Nutty } \\
\text { Physical } \\
\text { Compressibility Instron } \\
\text { Moisture content } \\
\text { Volume } \\
\text { Height }\end{array}$ & $\begin{array}{l}0,71 \\
0,61 \\
0,84 \\
0,70\end{array}$ & $\begin{array}{l}\mathbf{0 , 7 3} \\
0,60 \\
0,83\end{array}$ & $\begin{array}{l}0,94 \\
-0,73 \\
-0,79 \\
0,66\end{array}$ & $\begin{array}{l}0,68 \\
0,65\end{array}$ & $\begin{array}{l}0,76 \\
0,94 \\
\mathbf{0 , 9 0} \\
\mathbf{0 , 9 2}\end{array}$ & 0,78 & 0,61 & 0,65 & $\begin{array}{c}0,85 \\
0,80 \\
-0,83\end{array}$ & 0,61 & $\begin{array}{l}-0,75 \\
-0,77 \\
-0.62 \\
-0,60\end{array}$ & $\begin{array}{l}-0,76 \\
0,67 \\
-0,67\end{array}$ & $-0,63$ & $\begin{array}{l}0,64 \\
0,61\end{array}$ & & $\begin{array}{l}\mathbf{0 , 8 0} \\
0,68 \\
0,69\end{array}$ & 0,72 & $\begin{array}{l}\mathbf{0 , 7 8} \\
\mathbf{0 , 6 7} \\
\\
-0,80 \\
\\
-0,78 \\
-0,64 \\
-0,63\end{array}$ & $\begin{array}{l}0,68 \\
0,92 \\
0,97\end{array}$ & $\begin{array}{l}0,69 \\
\mathbf{0 , 9 1} \\
\mathbf{0 , 9 7}\end{array}$ & $\begin{array}{l}0,80 \\
0,92 \\
0,91\end{array}$ \\
\hline
\end{tabular}


indicated that the moisture content was not affected by batter storage and that the sensory moistness ratings reflected the analysed moisture content. On the contrary, the muffins with total oil replacement showed decreased moisture content with increased batter storage time while the sensory ratings of mouthfeel moistness did not differ significantly.

\section{Correlations of sensory attributes and physical} measurements Table 6 presents a summary of significant $(p<0,0001 ; r>0,6)$ correlations between sensory attributes and between sensory attributes and physical measurements. Significant correlations between sensory and physical measurements of crumb colour lightness were found, indicating that colour lightness intensity ratings increased as lightness L values increased. Significant correlations between sensory ratings for crust and crumb colour lightness and crust gloss indicated that colour lightness was closely associated with crust gloss or light reflection. Although the sensory ratings for compressibility did not correlate significantly with Instron measurements, significant correlations were obtained between sensory compressibility and cell size, crumb tenderness and crumbliness at initial bite, indicating that compressibility increased with increased cell size, tenderness and crumbliness. Significant negative correlations were found between the Instron measurement of compressibility and the sensory ratings for crumb tenderness and crumbliness after chewing, indicating that the higher the force required to attain a specified compression, the lower the sensory panel rated the muffins in terms of crumb tenderness and crumbliness. Volume versus crust and crumb colour lightness correlated significantly the bigger volume the lighter and brighter because more light was reflected.

Moisture content correlated significantly with volume, height, crust gloss and Instron compressibility, indicating that the muffins with higher moisture content were bigger, brighter and firmer. Significant negative correlations were, however, found between moisture content and crumbliness after chewing and adhesiveness, indicating that increased moisture content related to decreased crumbliness and increased adhesiveness (a high rating related to absence of adhesiveness). The more moisture, the firmer and the more oil the more tender, compressible and crumbly the muffins were. These results correspond with some of Cauvain's findings (1991) which indicated that cake crumb with higher moisture levels was less crumbly and more cohesive. Cauvain (1991) stated that moisture content might be considered as the single most meaningful measurement related to texture of baked products. Sensorily perceived moistness did not correlate significantly with any of the texturerelated attributes or moisture content. Flavour also did not correlate significantly with sweet or nutty taste. Although moisture content plays an important role in determining the rate of microbial growth, moisture content did not correlate significantly with total AMP counts in this study, probably because these counts were all relatively low.
Cluster analysis Taking a maximum Euclidian distance between types to be one unit in order to establish similarity of types, Formula 1 (full-fat control) with its combinations of different batter refrigeration periods fell into one cluster with the other two formulas (with $80 \%$ and $100 \%$ oil replacement) and their combinations into a second cluster. This means that the full-fat control was evaluated similarly for all the sensory as well as physical attributes but differed from the two experimental formulas with Simplesse ${ }^{\circledR}$.

\section{CONCLUSION}

The objective of this study was to examine the effects of batter refrigeration and oil replacement on the characteristics of high-fibre muffins. The main findings indicated that oil replacement had more pronounced effects on the characteristics of the muffins than either $24 \mathrm{~h}$ or $48 \mathrm{~h}$-refrigeration of the batter. The lighter crumb colour of the muffins with Simplesse $\AA$, irrespective of batter age, was due to the slight acidity and more moisture available than optimum for the Maillard reaction to take place. Although all treatments influenced quality with batter storage, it seemed that the experimental muffins with Simplesse $\AA$ were more resistant and tended to retain more characteristics during refrigeration than the control muffins. It was also noted that no yeasts or moulds were detected and that neither oil replacement nor batter refrigeration had any effect on total AMP counts of the baked products, strengthening the idea of the safety of batter refrigeration.

According to the sensory and physical results, it is concluded overall that oil replacement with Simplesse $\AA$ resulted in products that showed better stability towards batter refrigeration than the full-fat control muffins. The results also indicated that the experimental muffins baked from refrigerated batter, although different from the freshly baked full-fat control muffins, were still of comparable quality as shown by the high mean ratings allocated for all the characteristics measured. It is, therefore, recommended that where indicated the experimental low-fat high-fibre batter can be refrigerated up to 48 hours without significantly adverse effects on quality characteristics or microbiological safety.

\section{REFERENCES}

ALAIS, C \& LINDEN, G (1991): Food biochemistry. Chichester. Ellis Horwood.

AOAC (1984): Official methods of analysis of the Association of Official Analytical Chemists. $14^{\text {th }}$ ed. AOAC Washington, DC.

ARMBRISTER, WL \& SETSER, CS (1994): Sensory and physical properties of chocolate chip cookies made with vegetable shortening or fat replacers at 50 and $75 \%$ levels. Cereal Chem 71(4):344-351.

BEAN, MM \& SETSER, CS (1992): Polysaccharides, sugars, and sweeteners, in BOWERS, J. Food theory and applications. $2^{\text {nd }}$ ed. New York. MacMillan.

BOSMAN, MJC, VORSTER, HH, DREWNOWSKI, A, 
STEYN, HS \& SCHöNFELDT, HC (1996): Characteristics of high-fibre muffins containing various levels of fat substitute. SA J Food Sci Nutr 8(2):49-54.

BOSMAN, MJC, VAN AARDT, AM, VORSTER, HH \& DREWNOWSKI, A (1997a): Dietitians' attitude towards fat substitutes and the acceptability of high-fibre muffins containing Simplesse ${ }^{\circledR}$. SA J Food Sci Nutr 9(2):61-68.

BOSMAN, MJC, VORSTER, HH, DREWNOWSKI, A \& STEYN, HS (1997b): Consumer acceptance of high-fibre muffins containing Simplesse $\AA$. J Dietet Home Econ 25 (2):90-99.

BOSMAN, MJC, VORSTER HH \& STEYN, HS (1998): The effect of storage on the characteristics of high-fibre muffins with different levels of a protein-based fat substitute. J Fam Ecol Consum Sci 26(2):131-144.

CAMPBELL, AM (1992): Flour, flour mixtures, and other cereal products, in BOWERS, J Food theory and applications. $2^{\text {nd }}$ ed. New York. Macmillan.

CAUVAIN, SP (1991): Evaluating the texture of baked products, SA J Food Sci Nutr 3(4):81-86.

CHARLEY, H (1986): Food science. New York. Macmillan. CONFORTI, FD, CHARLES, SA \& DUNCAN, SE (1996): Sensory evaluation and consumer acceptance of carbohydrate - based fat replacers in biscuits. J Consum Stud Home Econ 20(3):285-296.

CONFORTI, FD \& SMITH, PM (1998): Effects of selected emulsifiers, enzymes and a carboydrate-based fat substitute on physical and sensory characteristics in a low-fat muffin. $J$ Consum Stud Home Econ 22(21):91-96.

CORLISS, GA (1992): Protein-based fat substitutes in bakery foods. Am Inst Baking Research Department Technical Bulletin (October)XIV:(10)1-8.

DORKO, CL \& PENFIELD, MP (1993a): Melt point of encapsulated sodium bicarbonates: Effect on refrigerated batter and muffins baked in conventional and microwave ovens. $J$ Food Sci 58(3):574-578.

DORKO, CL \& PENFIELD, MP (1993b): Particle size of encapsulated sodium bicarbonates: Effects on refrigerated batter and muffins baked in conventional and microwave ovens.
J Food Sci 58(3):579-582.

ELLIOT, RP (1980): Microbial ecology of foods. Volume 2. New York. Academic Press.

FARIDI, H (1995): The state of the U.S. Baking Industry. Cereal Foods World 40(3):SR-7-SR-12

FULTON, L \& HOGBIN, M (1993): Eating quality of muffins, cake, and cookies prepared with reduced fat and sugar. J Am Diet Assoc 93(11):1313-1316.

GIBSON, LA (1995): The Quest for Fresh. Satisfying the customers' desire for just-made taste. Cereal Foods World 49(3):SR-16-SR-17.

HOGBIN, M \& FULTON, L (1992): Eating quality of biscuits and pastry prepared at reduced fat levels. J Am Diet Assoc 92(8):993-995.

McWILLIAMS, M (1997): Foods. Experimental perspectives. $3^{\text {rd }}$ ed. Columbus, Ohio. Prentice Hall.

MARTH, EH (1998): Extended shelf life refrigerated foods: microbiological quality and safety. Food Technol 52(2):5762.

MATTHEWS, RH, KIRKPATRICK, ME \& DAWSON, EH (1965): Performance of fats in muffins. J Am Diet Assoc. 47 (10):201-204

NEWMAN, RK, ORE, KC, ABBOTT, J \& NEWMAN, CW (1998): Fiber enrichment of baked products with a barley milling fraction. Cereal Foods World 43(1):23-25.

QUINN, L (1995): Development of a bran muffin recipe for cook-chill service systems. J Nutr Recipe \& Menu Development 1(4):55-67.

SAS INSTITUTE INC. (1988): SAS/STAT: Users guide. Release 6.03 ed. Inc. Cary NC. SAS Institute.

SCHIRLE-KELLER, JP, REINECCIUS, GA \& HATCHWELL, LC (1994): Flavor interactions with fat replacers: effects of oil level. J Food Sci 59(4):813-815, 875.

SLOAN, AE (1994): Top ten trends to watch and work on. Food Technol 48(July):89-100.

SOUTH AFRICAN BUREAU OF STANDARDS (SABS) (1998): SABS Catalogue, SABS method 756 and ISO method 7954 . 